\title{
Party Elites or Manufactured Doubt? The Informational Context of Climate Change Polarization
}

\author{
***Forthcoming in Science Communication***
}

\author{
Eric Merkley \\ University of British Columbia \\ eric.merkley@alumni.ubc.ca \\ 1866 Main Mall - C425 \\ Vancouver, BC V6T $1 Z 1$ \\ ORCID: 0000-0001-7647-9650
}

\author{
Dominik A. Stecula \\ University of British Columbia \\ d.stecula@alumni.ubc.ca \\ 1866 Main Mall - C425 \\ Vancouver, BC V6T $1 Z 1$ \\ ORCID: 0000-0001-6724-7559
}

Acknowledgements: We thank Paul Quirk and Fred Cutler for financial support, Brendan Nyhan, Alan Jacobs, Gyung-Ho Jeong, Philip Habel, Edana Beauvais and Stuart Soroka for useful comments, and Zahara Baugh for her research assistance. We also thank the Social Science and Humanities Research Council for funding both of our doctoral dissertations of which this project is a critical part. The data reported in this paper came from LexisNexis Academic, Lexis.com, and Factiva. Both authors contributed equally to each component of the discussed research and the writing of this paper. 
Abstract: Americans polarized on climate change despite decreasing uncertainty in climate science. Explanations focused on organized climate skeptics and ideologically-driven motivated reasoning are likely insufficient. Instead, Americans may have formed their attitudes by using party elite cues. We conduct analyses on over 8,000 print, broadcast, and cable news stories. We find that coverage became increasingly partisan as climate change rose in salience, but climate skeptics received scant attention. Democratic messages were more voluminous and consistently pro-climate science, while Republican messages have been scarcer and ambiguous until recently. This suggests Republican voters took cues from Democratic elites to reject climate science. 
A substantial segment of the American public, primarily Republican Party supporters, does not believe in the scientific climate change consensus according to public opinion polling (Pew Research Center, 2016). However, this was not always the case (Krosnick et al., 2000). So why exactly did Republicans become more skeptical of climate science at a time when it became increasingly certain (NASA, 2018; Dunlap et al., 2016)? Prevailing theories have focused on the role of the fossil fuel industry and allied conservative organizations in orchestrating a successful media campaign to spread doubt about climate science (Dunlap \& Jacques, 2013; Dunlap \& McCright, 2011), or on the importance of ideologically-motivated cognition (Campbell \& Kay, 2014; Dixon et al., 2017; Kahan et al., 2011; Kahan, 2013). In this paper, using detailed content analysis of 30 years of news coverage of climate change, we provide evidence that points to an alternative explanation: party elite persuasion communicated through the mass media.

Numerous studies have attempted to provide explanations for climate science skepticism. One line of inquiry has focused on the role of an interconnected web of fossil fuel-supported advocacy groups and conservative think tanks - the infamous "merchants of doubt" (Conway \& Oreskes, 2010). In this account, these groups used their combined organizational clout to support contrarian scientists casting doubt on climate change in their research and in the media (Dunlap \& Jacques, 2013; Farrell, 2016a, 2016b; Jacques et al., 2008). Journalists are seen as unwittingly complicit in this process by providing 
balanced coverage to satisfy professional norms (Boykoff \& Boykoff, 2007; Dunlap \& McCright, 2011), while conservative outlets deliberately disseminate messages from these groups in order to undermine the public's confidence in climate science (Dunlap \& McCright, 2011). The result is that a confusing signal on the state of climate science is sent to the public.

There is little doubt that the fossil fuel industry and allies in the conservative movement have played an important role in ensuring that Republican Party elites have been reluctant climate warriors at best, or at worst, strident climate science denialists (Dunlap \& McCright, 2011). However, not a lot of empirical evidence has been mustered to illustrate how often their message of denial is carried by the media. Exactly how successful have these groups been in propagating doubt in coverage of climate change? We should expect them to command a significant share of media coverage and for that to have increased over time with polarization if they played a prominent role in aggregatelevel climate polarization.

More importantly, it is unclear theoretically why we would expect the uncertainty sown by organized climate skeptics on its own to result in polarization between Democratic and Republican Party supporters. Scholars have thus come to recognize the importance of ideology and motivated reasoning in creating a polarized public. Most prominently, Kahan (2013) posits that citizens interpret facts, like expert consensus, 
through the lens of their cultural values. They seek out and absorb information from experts that share their cultural predispositions (Kahan et al., 2011). Other scholars have shown that resistance to climate science is, to some degree, rooted in opposition to regulation, and that by shifting discourse to emphasize market-friendly solutions to mitigation we can lower conservative resistance to climate science (Campbell \& Kay, 2014; Dixon et al., 2017). The implication of this line of research is that we might be able to reduce polarization by framing debates or proposing solutions in ways that are compatible with conservative values.

There is no doubt that values and ideology are both playing an important role in influencing climate change attitudes, but there are reasons to suspect that it might not be the whole story. First, there is ample evidence that most Americans do not possess consistent ideological predispositions (Converse, 1964; Achen \& Bartels, 2016; Kinder \& Kalmoe, 2017). Second, these approaches do not easily address the fact that Republican supporters were once as likely to believe climate science as Democrats (Krosnick et al., 2000). Lastly, it is peculiar that the most market friendly way to reduce emissions, carbon pricing, is much less popular among Republicans than Democrats, and this is true even with revenue recycling (Amdur et al., 2014). In broader strokes, most people who label themselves as very conservative are anything but on many fiscal issues (Barber \& Pope, 2017; Drutman, 2017). 
Another account of climate change polarization can be found in political science theory on opinion formation. Scholars have shown that public opinion often follows, rather than leads, elite discourse on issues (Lenz, 2012; Zaller, 1992). This happens for a couple reasons. First, rational choice approaches to opinion formation inform us that people use cues, or short-cuts, in their information environment to make cognitively efficient decisions, such as from parties and their elites (Berinsky, 2009; Cohen, 2003; Conover \& Feldman, 1989; Kam, 2006; Lupia, 1994; Lupia \& McCubbins, 1998; Nicholson, 2012; Popkin, 1991). Second, psychological and sociological theories tell us that most Americans harbour strong positive or negative affective attachments to both political parties because partisanship and negative partisanship both form a critical part of their social identity (Green et al., 2002; Iyengar et al. 2012). Citizens draw on these affective attachments to guide their processing of information (Lodge \& Taber, 2014). They tend to be persuaded by those they like and trust, and instinctively oppose arguments from those they dislike or distrust. In either case, it is the mass media that plays a crucial role in disseminating these cues to the public by reflecting the broad parameters of elite debate (Althaus et al., 1996; Bennett, 1990; Dalton et al., 1998), and it is the most politically attentive citizens that are attuned to these signals in their information environment (Berinsky, 2009; Zaller, 1992). 
Of course, not all elite cues come from parties. Some might come from other political actors such as organized climate skeptics. But, political science theories on partisan identification and opinion formation give us reason to expect cues from party elites will be substantially more influential because of their anchoring in social identity. Consequently, the increasing embrace of climate science skepticism by Republican voters can likely be explained by party elite cuing as communicated through the mass media. There are strong signs suggesting this might be the case. First, the gap between Republicans and Democrats on concern over climate change is highest among those with knowledge of the issue and those that are politically attentive - in other words, those most attuned to elite debate (Guber, 2013; Tesler, 2017). Second, recent work has also shown that climate skepticism is correlated with the position of respondents' local representatives (Mildenberger \& Leiserowitz, 2017), while concern about global warming ebbs and flows with policy action, such as congressional roll call votes and committee hearings (Carmichael \& Brulle, 2017). Finally, Tesler (2017) shows with an experimental manipulation that Republican attitudes to climate science would soften if their elites changed course, but that this did not apply in the case of attitudes towards evolution. However, there have been few systematic media content analyses that can allow us to show the relative availability of cues or frames over time on climate change. We should expect such cues from party elites to be present in a significant and growing share of 
climate change coverage if it is playing an important role in the aggregate-level polarization on climate science.

To explore this possibility, we gathered what constitutes a significant slice of the media environment for Republican Party supporters from Lexis and Factiva. Our corpus includes high circulating and traditionally conservative newspapers like The Wall Street Journal, Dallas Morning News, Houston Chronicle, San Diego Union-Tribune, and the Chicago Tribune, broadcast sources like $A B C, N B C$, and $C B S$, and the conservative cable news network Fox News.

Although this is by no means the entirety of the media environment for Republican supporters over this time period, we do capture a significant portion of it. The Wall Street Journal is one of the top three circulating newspapers in the country and is the flagship newspaper of the conservative movement. ${ }^{1}$ The other newspapers have editorial sections that frequently endorse Republican presidential candidates, ${ }^{2}$ and, with the exception of the Chicago Tribune, have circulation bases in areas that lean Republican (Gentzkow \& Shapiro, 2010). Fox News is also included as the most important outlet in the conservative media echo chamber through this period and as the media organization most clearly associated with climate skepticism (Feldman et al. 2012). These are sources Republicans are likely to be exposed to or to select into. Conservative media has also been found to be

\footnotetext{
${ }^{1}$ Data provided by the Alliance for Audited Media (https://auditedmedia.com/).
}

${ }^{2}$ www.noahveltman.com/endorsements 
most likely to disseminate information from organized climate skeptics (Dunlap \& McCright, 2011).

Finally, we bring in broadcast sources because of audience size. According to the Pew Research Center, about 24 million people watch $A B C, N B C$ and $C B S$ on any given night, compared to about 3 million people combined who watch Fox News, CNN and $M S N B C$ in prime time (Pew Research Center, 2017). Taken together, these sources likely played an important role in shaping Republican attitudes toward climate change. We used supervised machine learning to purge our sample of irrelevant articles. More information on the procedure used can be found in the Online Appendix. ${ }^{3}$ In total, this resulted in a sample of 6,086 newspaper articles, 1,564 broadcast transcripts, and 661 Fox News transcripts.

We developed a dictionary to capture references to experts, parties, and politicians in climate change coverage by assembling a list of key terms like researcher, senator, governor, or Republican, and names of those in each party's national leadership who may not have their party referenced in text. ${ }^{4}$ We also built dictionaries of organizations linked to climate change skepticism and over 500 contrarian scientists based on lists previously

3 The Online Appendix referenced here and throughout is available on the authors' personal websites: https://ericmerkley.com/publications/ and http://www.stecula.com/research.html ${ }^{4}$ These leadership positions include presidents and presidential nominees, vice presidents, speakers of the House, and Senate and House majority and minority leaders. More discussion can be found in the Online Appendix. 
compiled by scholars (Anderegg et al., 2010; Farrell, 2016b). ${ }^{5}$ This allowed us to generate counts of articles that contained references to any of the above information sources. All dictionaries can be found in Tables A1 through to A8 in the Online Appendix. They were used in conjunction with the automated content analysis software Lexicoder to build measures of cue sources in climate coverage between 1980 and 2014. For the following analyses we present a combined organized climate skeptics measure that captures all of the organizations and individuals listed in the Online Appendix. We also break this down into separate relevant categories, such as contrarian scientists and dedicated climate denial organizations, conservative think tanks and advocacy groups, and industry organizations.

We validated our dictionaries by hand to ensure the results of automated coding were correct. Our operating definition of a cue was: an explicit or implicit stance on climate change science or climate change policy attributed to either the Republican or Democratic Party or their elites in a newspaper article. We validated each broadcast and cable transcript that Lexicoder had identified as having a Democratic or Republican reference by hand, as not all of these references will represent cues that signal a position for these actors on climate change. For newspapers, we hand coded a random sample of 350 articles for each party, stratified by presidential administration. We had an

\footnotetext{
${ }^{5}$ More details on how these scholars built their lists can be found in their respective works.
} 
undergraduate coder confirm our coding on a random sample of articles (200 with Republican cues; 100 with Democratic cues). Coder instructions can be found in Figure A1 of the Online Appendix. ${ }^{6}$ Validation confirmed that approximately 80 percent of references to party elites identified by Lexicoder could be classified as a cue, on average.

Panels A, C, and E in Figure 1 show the annual climate change coverage for our sources. Broadcast coverage was low and almost exclusively centered on major international events like the Rio and Kyoto conferences, and took off in 2006, potentially tied to the release of the movie An Inconvenient Truth, one of the highest grossing documentary films of all time. The flow of coverage has subsided since that peak, although in newspaper coverage there was a renewed interest in the topic during President Obama's second term.

\footnotetext{
${ }^{6}$ We had 90 percent agreement on the presence of Democratic cues with a Krippendorf's alpha score of $0.72(0.55-0.86,95 \% \mathrm{Cl})$, and 93 percent agreement on the presence of Republican cues with a Krippendorf's alpha of $0.75(0.57-0.89,95 \% \mathrm{Cl})$. After bootstrapping the distributions of these scores over 20,000 replications there is a 7 percent and 5 percent chance of this score falling below 0.6 if the entire population was coded.
} 


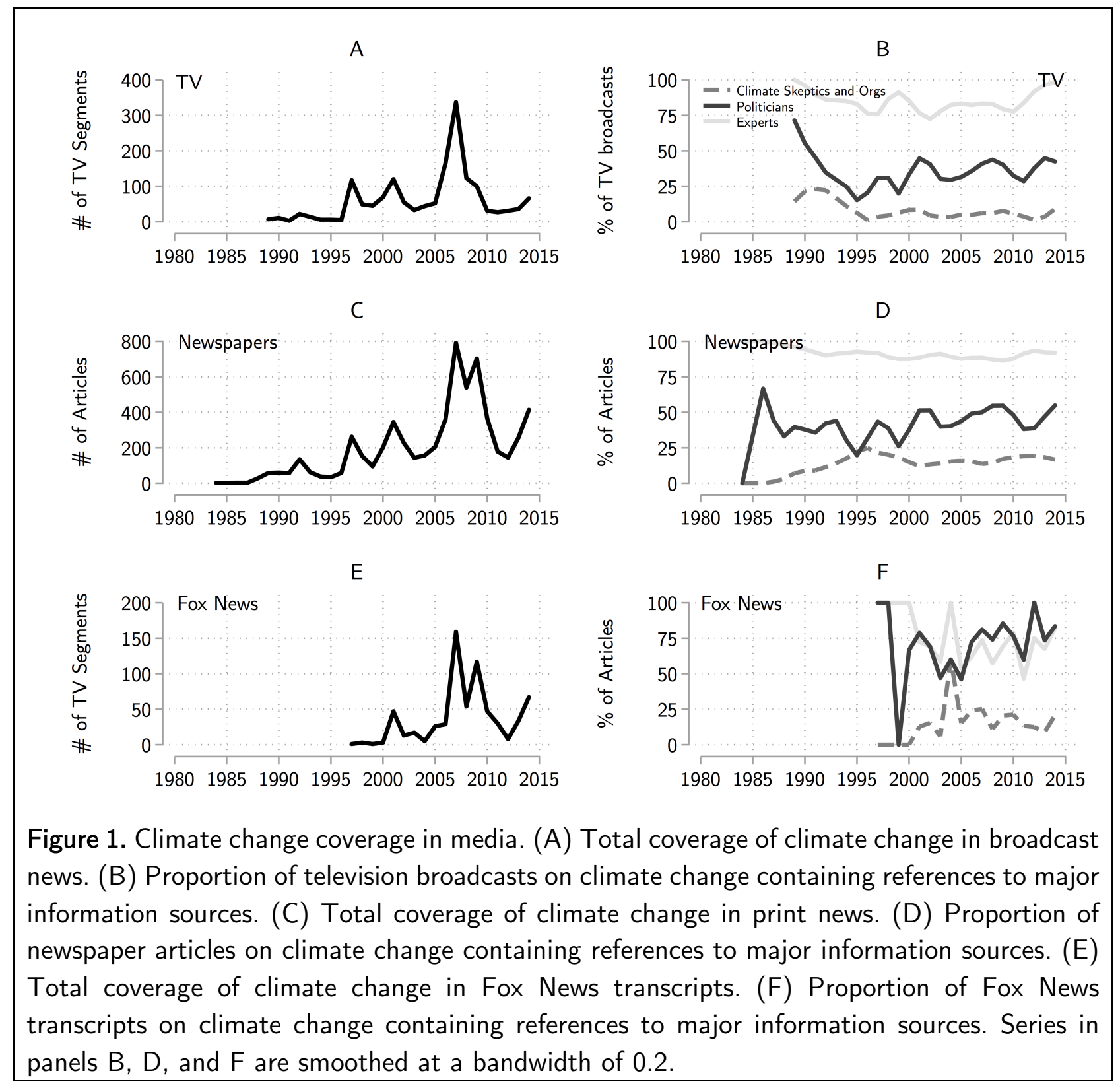

What is clear from panels $\mathrm{B}, \mathrm{D}$, and $\mathrm{F}$ of Figure 1 is that a vast majority of broadcasts and newspaper articles about climate change feature some references to experts on the subject. However, they increasingly share space with party elites. Party cues were featured in only 25 percent of newspaper and broadcast coverage at the time of the Kyoto 
negotiations when climate change emerged as something more than a niche environmental issue. This climbed to approximately 50 percent by 2014. The same was true in Fox News shown in panel $\mathrm{F}$, though with a higher baseline. Their coverage is consistently more partisan than other outlets in this sample. Combined with the large increase in salience after 2006, more persuasive cues and messages from parties are reaching the public than ever before across all our media. In contrast, contrarian scientists and climate skeptic organizations and have had a comparatively minimal and perhaps even diminishing presence in both mainstream and, surprisingly, Fox News coverage of climate change, as shown in those same panels in Figure 1. This does not mean Fox News' coverage is not laced with climate skepticism. It does mean that such skepticism is typically not cloaked in the pseudo-authority of organized climate skeptics. 


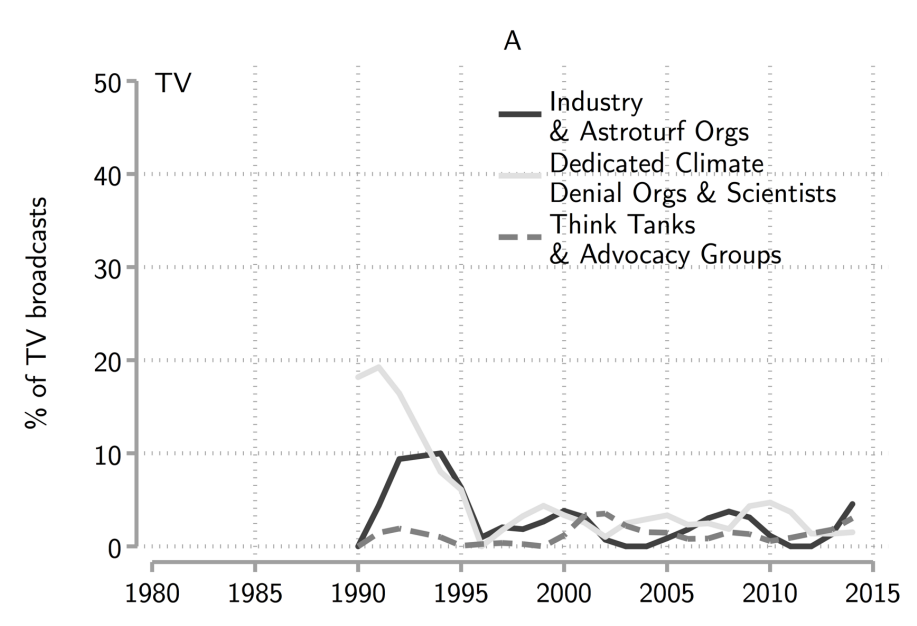

B

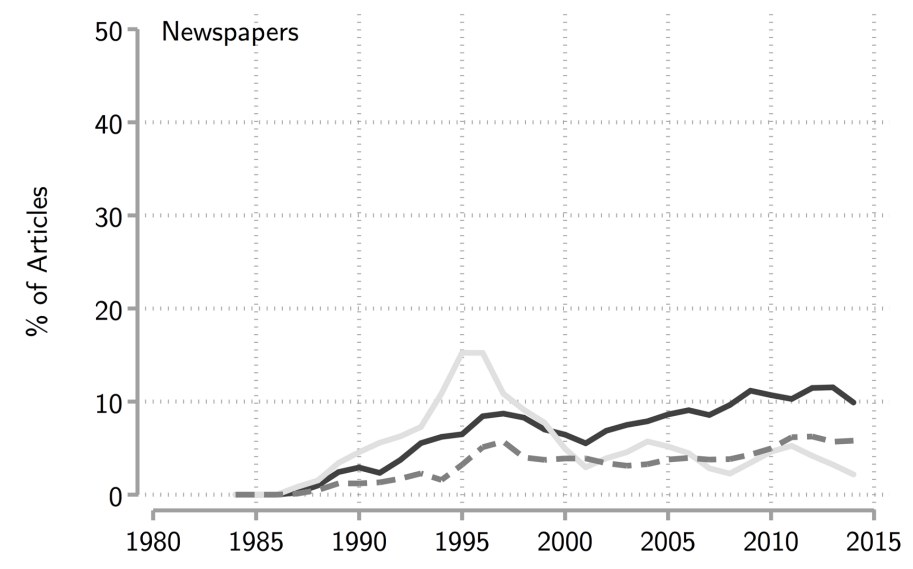

$\mathrm{C}$

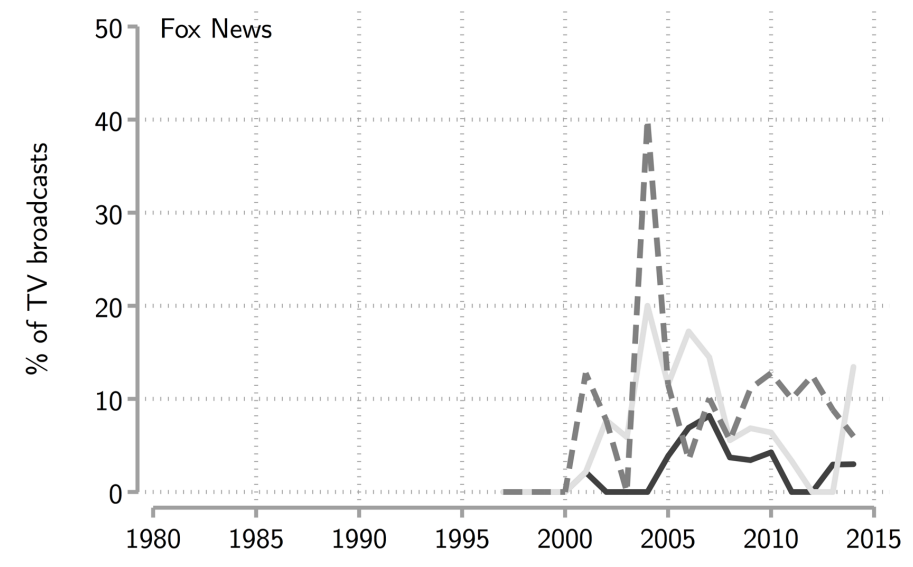

Figure 2. Breakdown of the climate denial cues in climate change coverage in broadcast and print media. (A) Estimated proportion of television broadcasts with references to organized climate skeptics. (B) Estimated proportion of newspaper articles with references to organized climate skeptics. (C) Estimated proportion of Fox News transcripts with references to organized climate skeptics. All series are smoothed at a bandwidth of 0.2 . 
A closer look at the coverage of organized climate skeptics, as shown in Figure 2, reveals how marginal their impact has been in the media. Contrarian scientists and organizations dedicated to casting doubt on climate science have seen their presence in coverage decline over the years, even in Fox News, while their occurrence in the television coverage is now effectively non-existent. More prominent in the news are industry and conservative movement groups. The former are comprised of companies like Exxon and industry-led organizations like the now defunct Global Climate Coalition. The latter include strident advocacy organizations like the Heartland Institute and more mainstream conservative think tanks like the American Enterprise Institute (AEI).

Although all of the groups in our dictionary are tied to climate skepticism, against expectations these organizations do not consistently send messages in climate change coverage that can be characterized as denialist. Some groups, like the Heartland Institute, are consistently denialist, but others, like $C A T O$ or the $A E I$, are not. At times, some of their scholars endorse climate science in the media, though they tend to cast a skeptical eye on regulation-heavy approaches to climate mitigation. Industry groups are even less consistently denialist. Many of the actors identified in the dictionary as having links to climate skepticism have changed course over the period of our study, including Exxon. According to our manual coding results, only 16 percent of all industry cues featured 
messages that explicitly advocated climate denialism, compared to 43 percent for conservative think tanks and advocacy organizations, which declined to 31 percent after 2005. ${ }^{7}$ Again, the same holds for Fox News. Only 39 percent of industry cues signaled skepticism toward climate science, while 48 percent of think tank messages did the same.

Our analysis indicates that organized climate skeptics are a heterogeneous group that is not as consistent in its climate denial as we may assume, at least in their media coverage. All told, contrarian scientists and sponsoring climate skeptic organizations have been remarkably unsuccessful in getting a message of denial heard in print or on the airwaves - even in the conservative media studied here.

In contrast, party cues have gone up in both their share and volume over time. This is not true for both parties, however. We can see that the presence of Democratic and Republican messages in the press have not moved in sync, as Figure 3 shows. Messages from Democratic elites have increased consistently, while messages from Republicans have, if anything, declined. This dominance is particularly true around the Kyoto Protocol, and in the post-Inconvenient Truth period - times when climate change was more robustly covered in the news. There is little difference in these trends between climate coverage in broadcast news, conservative newspapers, and Fox News.

\footnotetext{
${ }^{7}$ More dominant for conservative organizations, and particularly industry groups were concerns about the economic impact of specific policies and energy prices.
} 


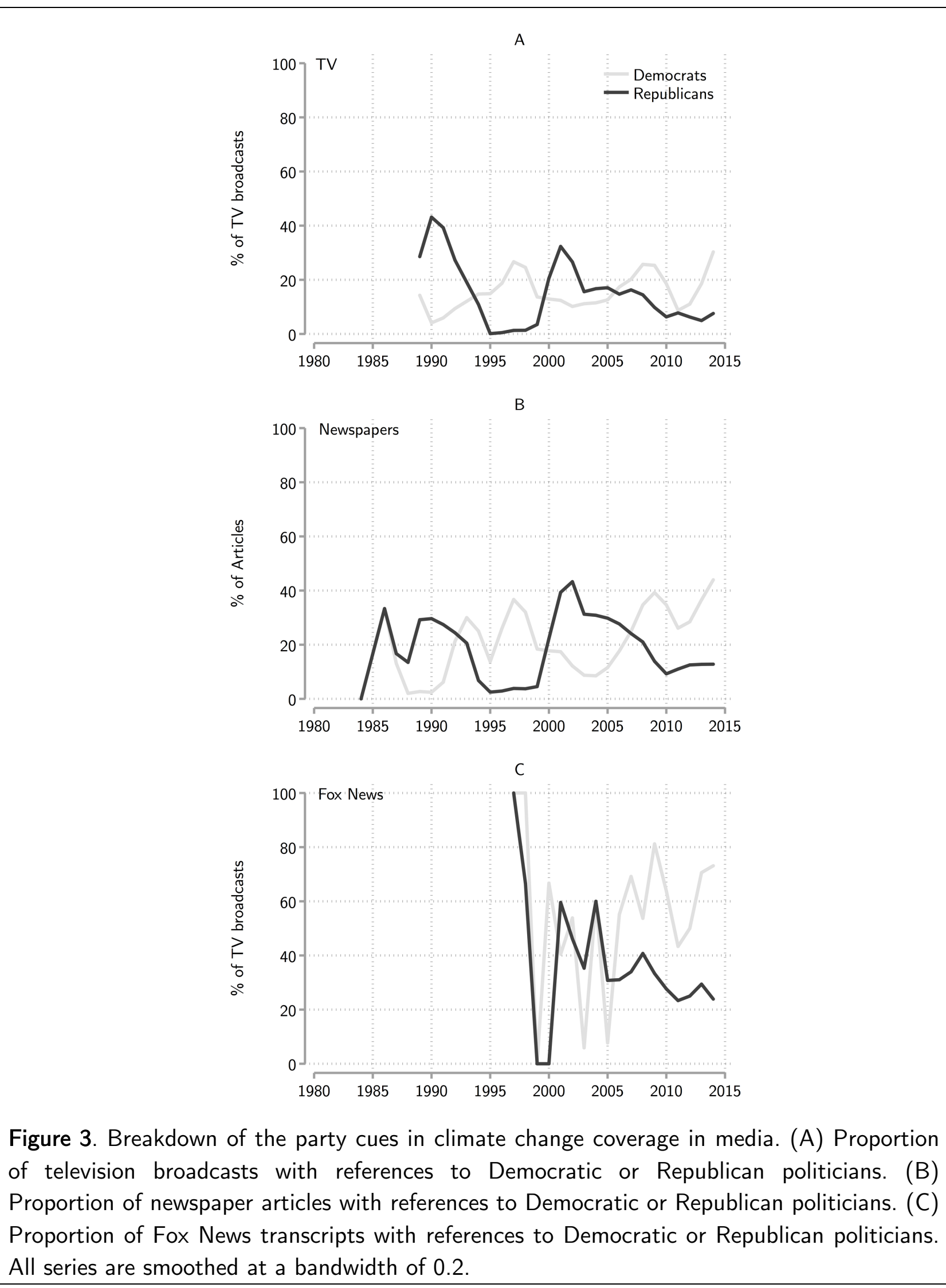


Another sign of the likely role of party elites, and particularly Democrats, in climate change polarization can be found when examining the messages they communicated in the media. We coded articles that contained verified party cues for direction and message. Pro-climate articles contained only cues with messages from a party that explicitly endorsed climate science or implicitly endorsed it by backing policy to address climate change. Anti-climate articles contained cues from a party with messages that explicitly rejected climate science or implicitly rejected the consensus by refusing to support policy action to address climate change. Anti-climate articles, however, could not contain proclimate cues from that party. Articles were coded as mixed if they contained cues that pointed in both directions for a given party. This was common for articles featuring Republican elites who tried to navigate a fine line between placating their supporting interest groups and catering to centrist public opinion. ${ }^{8}$ Lastly, we coded articles for whether or not they contained messages from Republican elites that casted doubt on climate science. We wanted to distinguish these articles from those where Republican elites focused only on economic concerns or on neither argument.

\footnotetext{
8 There was high agreement between our coding and that of our undergraduate research assistant with Krippendorf's alpha scores of 0.98 for Democratic messages and 0.83 for Republican messages. After bootstrapping the distribution of the Krippendorf's alpha scores over 20,000 replications, there is a less than 0.001 percent chance the score would fall below 0.6 in either case if the entire population was coded.
} 

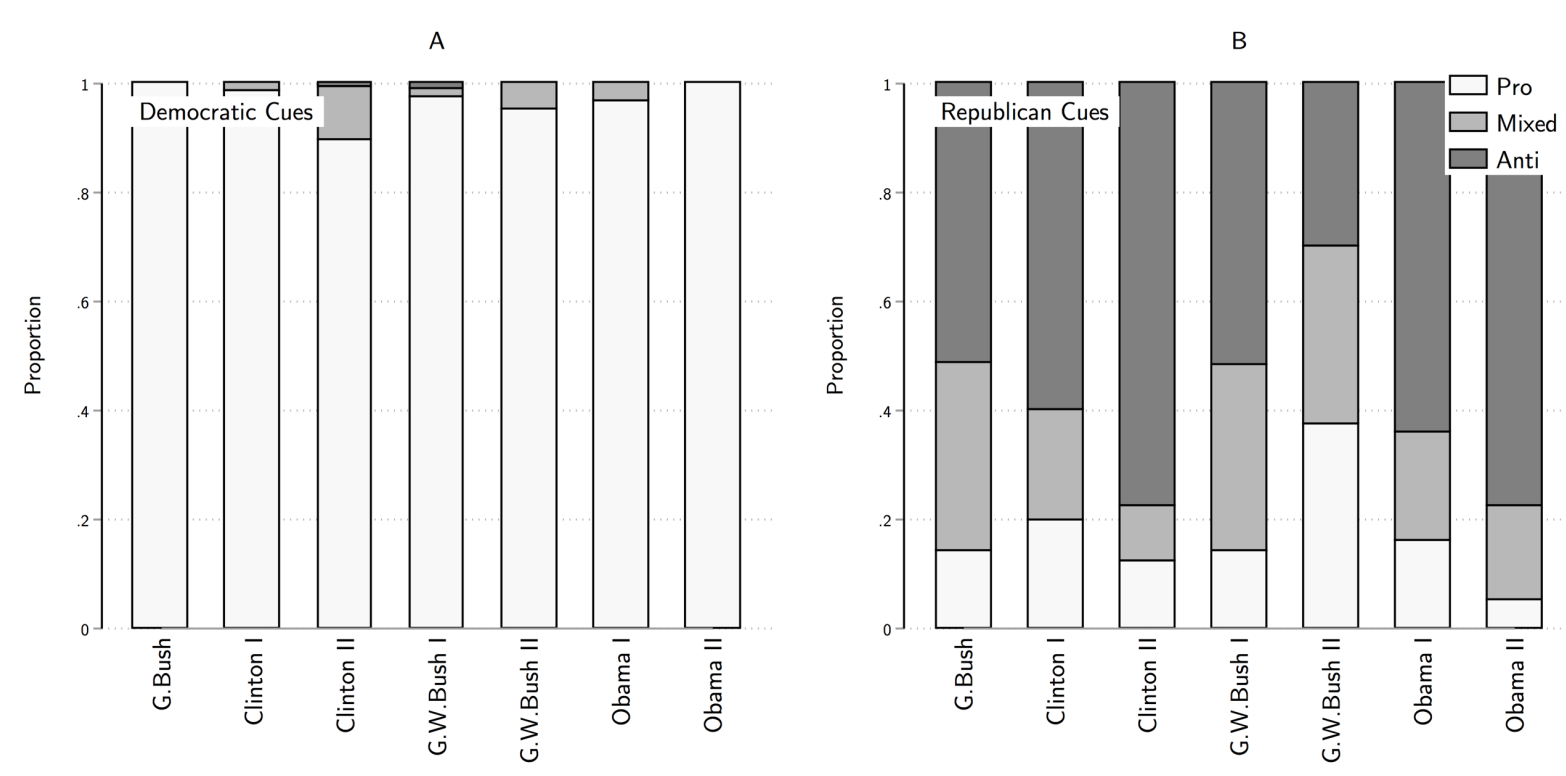

Figure 4. Messages from party elites in combined sample of media. (A) Democratic politicians. (B) Republican politicians.

Figure 4 shows the breakdown of articles with either pro-, mixed, or anti-climate messages for Democrats (panel A) and Republicans (panel B) in our entire media sample and across presidential administrations. Clearly, the Democrats took a consistently proclimate stance in the media over time. Republican messages, contrary to the prevailing narratives, were ambiguous. Only a fraction of Republican messages were anti-climate, though this has risen considerably in recent years. Even fewer messages were explicitly denialist. Only 25 percent of Republican messages cast doubt on climate science during the George Bush administration, falling to under 20 percent during George W. Bush's 
presidency. This, however, has risen to over 30 percent during the first Obama term and over 40 percent during his second term. ${ }^{9}$

Prior research has emphasized the tight connection between organized climate skeptics and Republican elites (Dunlap \& McCright, 2011), but there appears to be more daylight between the two than we might expect - at least in their presentation in the mass media. It is important to keep this information in context. Strident Republican denial of climate change is a relatively recent phenomenon, while polarization in the public on climate change is not. Further, messages of climate skepticism from Republicans and the "merchants of doubt" are comparatively much less frequent than Democratic elites, as shown in Figure A3 of the Online Appendix.

For many scholars, the so-called "Merchants of Doubt" and allied industry and conservative groups have played a starring role in the American public's polarization on climate change. They were able to exercise this influence by leveraging allies in conservative media and taking advantage of the proclivity of journalists to provide balance in coverage. However, our data show that these groups have commanded a small, and, if anything, declining presence in climate change coverage as the issue rose to prominence. This is true even with our sample's skew towards conservative media. We do not test causal propositions in this paper, but our findings suggest these groups are unlikely to

\footnotetext{
${ }^{9}$ A full breakdown of these measures across our three types of media can be found in Figure A2 in the Online Appendix. They show broadly similar results.
} 
have significantly influenced aggregate-level polarization on climate change in any direct fashion.

Other scholars have highlighted the importance of ideologically-driven motivated cognition. We do not doubt that this matters, but our data suggests there may be another important part of the story that has thus far been neglected in climate change communication research. A rich literature in political science has drawn our attention to the importance of party elites in shaping public opinion from the top, down (Berinsky, 2009; Cohen, 2003; Conover \& Feldman, 1989; Kam, 2006; Lupia, 1994; Lupia \& McCubbins, 1998; Nicholson, 2012; Popkin, 1991; Zaller, 1992), and the availability of cues from these actors has steadily risen over time through a combination of the increasingly partisan nature of coverage and rising issue salience. People learn about what positions they "should" hold as a Democrat or a Republican from the cues that are present in their information environment. This might help explain why highly educated and politically attentive Republicans are most skeptical about climate change, even when controlling for ideology - they are most attuned the elite debate in the media. Our findings further bolster an emerging literature on the role of elite cues in climate change polarization (Carmichael \& Brulle, 2017; Guber, 2013; Mildenberger \& Leiserowitz, 2017; Tesler, 2017) and highlight the need for future scholars to focus more attention on elite cues and partisan-driven motivated reasoning. 
Our results also provide some suggestive evidence that citizens may sometimes form opinions about politics from signals they receive from opposing party elites. Democratic messages were more consistent and increasingly available in the media over time, while Republican elites were less frequent and mixed in their messaging until recently, when much of climate change polarization had already occurred. It is possible that Republican voters were negatively persuaded by the clearer and more abundant signal sent by Democratic elites in the media. This is consistent with other research that identifies boomerang effects in science communication where frames or messages designed to persuade may, in fact, do the opposite among certain segments of the public (Hart \& Nisbet, 2012). It is also in line with prior research showing that cues from an opposing party are as influential in persuasion as cues from the party with whom the voter identifies (Berinsky, 2009; Nicholson, 2012), though more research has to be done to test this causal proposition in the context of climate change with either aggregate time series analyses or an experimental design.

If the United States is to mobilize the cross-partisan societal consensus necessary to effectively tackle climate change, it is essential that we fully understand the factors that caused Americans to polarize on climate science. Much popular and scholarly attention has been focused on highlighting the role of organized climate skeptics and discrediting these actors in the public eye. More recently, there has been an effort to 
reframe scientific debates or advance policy solutions in ways conducive to conservative ideology. However, both of these efforts may, to a degree, miss the mark. We may only depolarize climate change by finding ways to bridge the divide between Republican and Democratic elites, as hopeless as that might sound in this hyper-partisan era. In short, scholars and science communicators need to take the role of party elites seriously. 


\section{References}

Achen, C. H., \& Bartels, L. M. (2016). Democracy for realists: Why elections do not produce responsive government. Princeton: Princeton University Press.

Althaus, S., Edy, J. A., Entman, R. M., \& Phalen, P. (1996). Revising the indexing hypothesis: Officials, media, and the Libya crisis. Political Communication, 13, 407421.

Amdur, D., Rabe, B. G., \& Borick, C. (2014). Public views on a carbon tax depend on the proposed use of revenue. Report for the Center for Local, State, and Urban Policy, Issues in Energy and Environmental Policy, 13, 1-9.

Anderegg, W. R. L., Prall, J. W., Harold, J., \& Schneider, S. H. (2010). Expert credibility in climate change. Proceedings of the National Academy of Science, 107, 12107-12109.

Barber, M., \& Pope, J. C. (2018). Does party trump ideology? Disentangling party and ideology in America. Working Paper.

Bennett, W. L. (1990). Toward a theory of press-state relations. Journal of Communication, 40:2, 103-125.

Berinsky, A. J. (2009). In time of war: Understanding American public opinion from World War II to Iraq. Chicago: University of Chicago Press.

Boykoff, M. T., \& Boykoff, J. M. (2007). Climate change and journalistic norms: A casestudy of U.S. Mass-media coverage. Geoforum, 38, 1190-1204.

Campbell, T. H., \& Kay, A. C. (2014). Solution aversion: On the relation between ideology and motivated disbelief. Journal of Personality and Social Psychology, 107:5, 809-824.

Carmichael, J. T., \& Brulle R. J. (2017). Elite cues, media coverage, and public concern: An integrated path analysis of public opinion on climate change, 2001-2013. Environmental Politics, 26, 232-252.

Cohen, G. L. (2003). Party over policy: The dominating impact of group influence on political beliefs. Journal of Personality and Social Psychology, 85(5), 808-822.

Conover, P. J., \& Feldman, S. (1989). Candidate perceptions in an ambiguous world: Campaigns, cues, and inference processes. American Journal of Political Science, 33, 917-940.

Converse, P. (1964). The nature of belief systems in mass publics. In Apter, D. (Ed.), Ideology and Discontent. New York: The Free Press of Glencoe, 206-261.

Conway, E. M., \& Oreskes, N. (2010). Merchants of doubt: How a handful of scientists obscured the truth on issues from tobacco smoke to global warming. New York: Bloomsbury Press.

Dalton, R. J., Beck, P. A., \& Huckfeldt, R. (1998). Partisan cues and the media: Information flows in the 1992 presidential election. American Political Science Review, 92:1, 111-126. 
Dixon, G., Hmielowski, J., \& Ma, Y. (2017). Improving climate change acceptance among U.S. conservatives through value-base message targeting. Science Communication, $39: 4,520-534$.

Drutman, L. (2017). Political divisions in 2016 and beyond: Tensions between and within the two parties. Report from the Democracy Fund Voter Study Group.

Dunlap, R. E., \& Jacques, P. J. (2013). Climate change denial books and conservative think tanks: Exploring the connection. American Behavioral Scientist, 57, 699-731.

Dunlap, R. E., \& McCright, A. M. (2011). Organized climate change denial. In Dryzek, J. S., Norgaard, R. B., \& Schlosberg, D. (Eds.), The Oxford Handbook of Climate Change and Society (vol. 1, chap. 10). New York: Oxford University Press.

Dunlap, R. E., McCright, A. M., \& Yarosh, J.H. (2016). The political divide on climate change: Partisan polarization widens in the U.S. Environment, Science and Policy for Sustainable Development, 58:5, 4-23.

Farrell, J. (2016a). Network structure and influence of the climate change countermovement. Nature Climate Change, 6, 370-374.

Farrell, J. (2016b). Corporate funding and ideological polarization about climate change. Proceedings of the National Academy of Science, 113, 92-97.

Feldman, L., Maibach, E. W., Roser-Renouf, C., \& Leiserowitz, A. (2012). Climate on cable: The nature and impact of global warming coverage on Fox News, CNN, and MSNBC. The International Journal of Press/Politics, 17:1, 3-31.

Gentzkow, M., \& Shapiro, J. M. (2010). What drives media slant? Evidence from U.S. daily newspapers. Econometrica, 78:1, 35-71.

Green, D. P., Palmquist, B., \& Schickler, E. (2002). Partisan hearts and minds: Political parties and the social identities of voters. New Haven, CT: Yale University Press.

Guber, D. L. (2013). A cooling climate for change? Party polarization and the politics of global warming. American Behavioral Scientist, 57, 93-115.

Hart, P. S., \& Nisbet, E. C. (2012). Boomerang effects in science communication: How motivated reasoning and identity cues amplify opinion polarization about climate mitigation policy. Communication Research, 39:6, 701-723.

Iyengar, S., Sood, G., \& Lelkes, Y. (2012). Affect, not ideology: A social identity perspective on polarization. Public Opinion Quarterly, 76, 405-431.

Jacques, P. J., Dunlap, R. E., \& Freeman, M. (2008). The organization of denial: conservative think tanks and environmental skepticism. Environmental Politics, 17, 349-385.

Kahan, D. M. (2013). Ideology, motivated reasoning, and cognitive reflection. Judgement and Decision Making, 8, 407-424.

Kahan, D. M., Jenkins-Smith, H., \& Braman, D. (2011). Cultural cognition of scientific consensus. Journal of Risk Research, 14:2, 147-174. 
Kam, C. (2005). Who toes the party line? Cues, values, and individual differences. Political Behavior, 27, 163-182.

Kinder, D. R., \& Kalmoe, N. P. (2017). Neither liberal nor conservative: Ideological innocence in the American public. Chicago: University of Chicago Press.

Krosnick, J. A., Holbrook, A. L., \& Visser, P. S. (2000). The impact of the fall 1997 debate about global warming on American public opinion. Public Understanding of Science, 9, 239-260.

Lenz, G. (2012). Follow the leader? How voters respond to politicians' policies and performance. Chicago: University of Chicago Press.

Lodge, M., \& Taber, C. (2014). The rationalizing voter. New York: Cambridge University Press.

Lupia, A. (1994). Shortcuts versus encyclopedias: Information and voting behavior in California insurance reform elections. American Political Science Review, 88, 63-76.

Lupia, A., \& McCubbins, M. (1998). The democratic dilemma: can citizens learn what they need to know? New York: Cambridge University Press.

Mildenberger, M., \& Leiserowitz, A. (2017). Public opinion on climate change: Is there an economy-environment tradeoff? Environmental Politics, 26(5), 801-824.

NASA. (2018). Scientific consensus: Earth's climate is warming. Available at: https://climate.nasa.gov/scientific-consensus/

Nicholson, S. P. (2012). Polarizing cues. American Journal of Political Science, 56, 5266.

Pew Research Center. (2016). The politics of climate. Available at: http://www.pewinternet.org/2016/10/04/public-views-on-climate-change-and-climatescientists/

Pew Research Center. (2017). Network News Fact Sheet. Available at: http://www.journalism.org/fact-sheet/network-news/

Popkin, S. L. (1991). The reasoning voter: Communication and persuasion in presidential campaigns. Chicago: University of Chicago Press.

Tesler, M. (2017). Elite domination of public doubts about climate change (not evolution). Political Communication: 1-21.

Zaller, J. (1992). The nature and origins of mass opinion. New York: Cambridge University Press. 